\title{
Relationship between restless leg syndrome and quality of life in uremic patients
}

\section{Üremik hastalarda huzursuz bacak sendromu ve yaşam kalitesi arasındaki ilişki}

\author{
Demet TEKDÖŞ DEMiRCiOĞLU, ${ }^{1}$ Gülis KAVADAR, ${ }^{2}$ Özgül ESEN ÖRE, ${ }^{1}$ Tuluhan Yunus EMRE, ${ }^{1}$ Umut YAKA
}

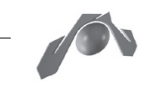

\begin{abstract}
Summary
Objectives: Patients with RLS suffer nonrestorative sleep, daytime sleepiness, fatigue, and concentration problems. In addition, dialysis itself effects the psychological and social life of the patient negatively. The aim of this study was to determine the prevalence of RLS in patients on regular hemodialysis, and its relationship with patients' quality of life, socio-demographic and laboratory data.

Methods: One hundred and eighteen stable chronic hemodialysis (HD) patients referring to the hemodialysis unit of Turkish Kidney Foundation and 49 patients that met IRLSSG diagnostic criteria were included into the study. IRLSSG Diagnostic Criteria and International Restless Leg Syndrome rating scale were used as a guideline to diagnose and evaluate the severity of RLS. Short form-36 health survey was used to evaluate the quality of life. For statistical analysis, the "SPSS for Windows" package program was used.

Results: A total of forty-nine patients, of whom 26 were female and 23 were male, that met IRLSSG diagnostic criteria were included into the study. Mean age of the patients was $61.35 \pm 13.17$ years. There was a negative correlation between the IRLSS score and SF36 Physical Score, Mental Score and Total Score, respectively $(p=0.018 r=-0.351, p=0.01 r=-0.380, p=0.00$ $\mathrm{r}=-0.499)$. There was no significant correlation between the IRLSS score and dialysis duration, blood ferritin and parathyroid hormone and other comorbid diseases.

Conclusion: RLS is a common distressing problem in patients with ESRD, which negatively impacts functional health status. Clinicians should be aware of the symptoms of RLS to decrease morbidities related with quality of life.
\end{abstract}

Key words: Dialysis; restless leg syndrome; quality of life.

\section{Özet}

Amaç: Huzursuz bacak sendromu (HBS) ăgrı, dinlendirici olmayan uyku, gündüz uyku bali ve konsantrasyon bozuklukları yaratan bir hastalıktır. Düzenli hemodiyalize giren son dönem böbrek yetersizliği olan hastalarda buzursuz bacak sendromunun sıklı̆̆ının artmış olabileceği düşünülmektedir. Bu çalışmada düzenli hemodiyalize giren hastalarda buzursuz bacak sendromu ve yaşam kalitesi arasındaki ilişkinin araştırılması amaçlandı.

Gereç ve Yöntem: Türk Böbrek Vakfı Diyaliz Ünitesine ayaktan başvuran 118 kronik hemodiyaliz hastası değerlendirildi. Uluslararası Huzursuz Bacak Sendromu Çalı̧̧ma Grubu’nun (IRLSSG) belirlediği tanı kriterlerne uyan 49 hasta çalışmaya dabil edildi. Huzursuz bacak sendromu sempromlarının şiddeti Uluslararası Huzursuz Bacak Sendromu Sinılama Skalası (IRLS) kullanilarak değerlendirildi. Yaşam kalitesini değerlendirmek amacıyla KısaForm-36 (KF-36) ölçeği kullanıldı. Hastaların demografik özellikleri, komorbid hastaliklar ve laboratuvar verileri kaydedildi. Istatistiksel analizde SPSS paket program kullanild.

Bulgular: Uluslararası Huzursuz Bacak Sendromu Çalışma Grubu tanı ölçütlerini karşılayan 26 kadın 23 erkek toplam 49 hasta

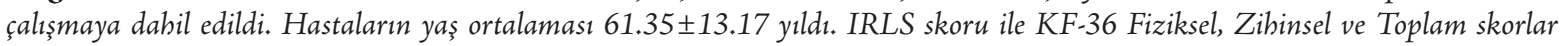
arasında istatistiksel açısından anlamlı negatif korelasyon saptandı ( $p=0.018 r=-0.351, p=0.01 r=-0.380, p=0.00 r=-0.499)$. IRLS skoru ile diyaliz süresi, yaş, serum ferritin, PTH ve komormid hastaliklar ile anlamlı ilişki bulunmadı $p>0.05$ ).

Sonuç: Huzursuz bacak sendromu diyalize giren son dönem bastalarda sık rastlanan bir sorun olduğu düşünülmektedir. Huzursuz bacak sendromuna bağh ağrı ve diğer semptomların son dönem böbrek yetersizlikli hastaların yaşam kalitesini kötü yönde etkileyebileceği düşünülerek bu yakınmalara yönelik tanı ve tedavi yaklaşımları bu bastaların yaşam kalitelerinin artırılmasına katkıda bulunacaktır.

Anahtar sözcükler: Diyaliz; huzursuz bacak sendromu; yaşam kalitesi.

\footnotetext{
'Department of Physical Medicine and Rehabilitation, Istanbul Memorial Hizmet Hospital, Istanbul, Turkey; ${ }^{2}$ Department of Physical Medicine and Rehabilitation, Istanbul Bagcilar Medicine Hospital, Istanbul, Turkey 'Iistanbul Memorial Hizmet Hastanesi, Fiziksel Tıp ve Rehabilitasyon Kliniği, Istanbul; ${ }^{2}$ Istanbul Bağcılar Medicine Hastanesi, Fiziksel Tıp ve Rehabilitasyon Kliniği, İstanbul
}

Submitted (Başvuru tarihi) 26.07.2014 Accepted after revision (Düzeltme sonrası kabul tarihi) 01.09.2014

Correspondence (İletişim): Dr. Demet Tekdöş Demircioğlu. Bahçelievler Mahallesi, Günȩs Sokak, No: 2-4, Bahçelievler, İstanbul, Turkey.

Tel: +90 - 212 - 4086666 e-mail (e-posta): drtekdos@gmail.com 


\section{Introduction}

Restless-legs syndrome (RLS) is a sensorimotor problem characterized by uncomfortable and unpleasant sensations of the legs that are worse during periods of inactivity and usually causes a severe sleep disorder. ${ }^{[1,2]}$

The diagnosis of RLS is clinical and as several conditions like neuropathy, radiculopathy, depression, varicose disorders and akathisia may mimic RLS, its definition has been clarified and standardized by internationally recognized diagnostic criteria, published in 1995 by the International Restless Legs Syndrome Study Group (IRLSSG). ${ }^{[2,3]}$ Some studies have indicated that $2-15 \%$ of the world's population may experience symptoms of RLS. ${ }^{[1]}$ In most cases, RLS is idiopathic and is called primary RLS. It may also be secondary to iron deficiency, uremia, pregnancy, peripheral neuropathy and drugs, such as antipsychotics, antidepressants and dopamine antagonists. ${ }^{[4]}$ RLS is common among patients on dialysis and the prevalence is estimated to be greater than in the general population. ${ }^{[4,5]}$

Patients with RLS suffer from disorders such as daytime sleepiness, tiredness and concentration problems. In addition, dialysis itself effects a patient's psychological and social life negatively. The experience of multiple losses, including kidney function, physical activity, sexual function, imployment impact significantly on the lives of patients. ${ }^{[6]}$ The aim of this study is to determine the prevalence of RLS in stable uremic patients and its relationship with patients' quality of life, sociodemographic and laboratory data.

\section{Materials and Methods}

Between March 2012 and April 2012, 118 stable chronic hemodialysis (HD) patients recruited from hemodialysis unit of Turkish Kidney Foundation and 49 patients that met IRLSSG diagnostic criteria were included to the study. Patients with RLS were screened by the same neurologist. The patients underwent HD therapy three times per week which session lasting approximetly 4 hours. An enoxaparin dose of 40-60 mg was administered intravenously before the beginning of each session and erythropoietin therapy was given after dialysis session to adjust hemoglobulin levels. Patients who were in catabolic state that include malignencies, HIV and opportu- nistic infections, who had neuropathies and received pharmacological treatment which could have effected quality of life were excluded from the study.

IRLSSG Diagnostic Criteria were used as a guideline to diagnose and evaluate severity of RLS. The four minimal criteria included: 1.urge to move the legs, usually accompanied or caused by uncomfortable leg sensations; 2. temporary relief with movement, partial or total relief from discomfort by walking or stretching; 3. onset or worsening of symptoms at rest or inactivity, such as when lying down or sitting; 4. an aggrevation or onset of symptoms in the evening or at night. ${ }^{[3]}$

International Restless Leg Syndrome rating scale was developed as a tool for assesing the severity of RLS. The 10-item questionnaire asks respondents to use Likert-type ratings to indicate how acutely the disorder has affected them over the course of the past week. Questions can be divided into two catagories: disorder symptoms (nature, intensity and frequency) and their impact (sleep issues, disturbances in daily functioning and resultant changes in mood).

Patients' rate each of ten questions on a scale from 0 to 4 . Four representing the most severe and frequent symptoms, 0 representing the least. Total scores can range from 0 to 40 .

\section{Short form 36 (SF-36) health survey}

Health related quality of life (HRQoL) has increasingly been recognized as an important aspect of health care delivery in chronic medical conditions. SF36 is a widely used and validated questionnaire for assessing HRQoL in populations including patients with ESRD. ${ }^{[7]}$ Short form 36 health survey is a generic test that measures QoL through the perception of health by the patient. It contains 36 items in 8 subscales: physical functioning, emotional role, bodily pain, general health, vitality, social functioning and mental health. SF-36 total score lies between 0 and 100. Higher scores indicate better health. Validation study of the Turkish version of SF-36 has been performed. ${ }^{[8]}$

Patients' age, gender, dialysis duration, blood ferritin and parathyroid hormone (PTH) and other comorbid diseases were recorded. Comorbidities were obtained from medical records of the patients. Patients 
Table 1. Clinical characteristics of the patients

\begin{tabular}{lcccc}
\hline & Minimum & Maximum & Mean & Std. Deviation \\
\hline Age (years) & 22 & 83 & 61.35 & 13.17 \\
Dialysis duration (years) & 1 & 24 & 9.52 & 6.971 \\
Ferritin & 14.0 & 3536,0 & 873.36 & 748.26 \\
Parathyroid hormone & 4.26 & 3332.00 & 580.34 & 588.103 \\
IRLSSG Score & 6 & 37 & 22.33 & 8.061 \\
\hline
\end{tabular}

Table 2. IRLSSG scores and SF-36 Scores of the patients

\begin{tabular}{lcccc}
\hline & Minimum & Maximum & Mean & Std. Deviation \\
\hline IRLSSG score & 6 & 37 & 22.33 & 8.061 \\
SF-36 PCS & 10 & 62 & 35.96 & 11.429 \\
SF-36 MCS & 19.4 & 55.1 & 33.507 & 8.3824 \\
SF-36 total score & 18.1 & 62.7 & 39.787 & 11.5051 \\
\hline
\end{tabular}

IRLSSG: International Restless Leg Syndrome Study Group; SF-36: Short Form-36. PCS physical component score, MCS mental component score.

included in the study provided a written informed consent and an approval for the study was obtained from the Local Ethical Committee.

\section{Statistical analysis}

For the statistical analysis, the "SPSS for Windows" program was used to assess study data, together with the descriptive statistical methods (average, standard deviation). The Pearson Correlation Coefficient was used in the comparisons. Results were assessed in the $95 \%$ confidence range, with a significance level of $\mathrm{p}<0.05$.

\section{Results}

One hundred and eighteen stable chronic hemodialysis (HD) patients recruited from hemodialysis unit and 49 patients that met IRLSSG diagnostic criteria were included to the study. 26 patients were female and 23 patients were male. Mean age of patients was $61.35 \pm 13.17$ years. Clinical characteristics and SF-36 scores of the patients are summarized in Table 1 and Table 2, respectively. Twenty three patients had severe-very severe symptoms and 26 patients had mild-moderate symptoms. There was no

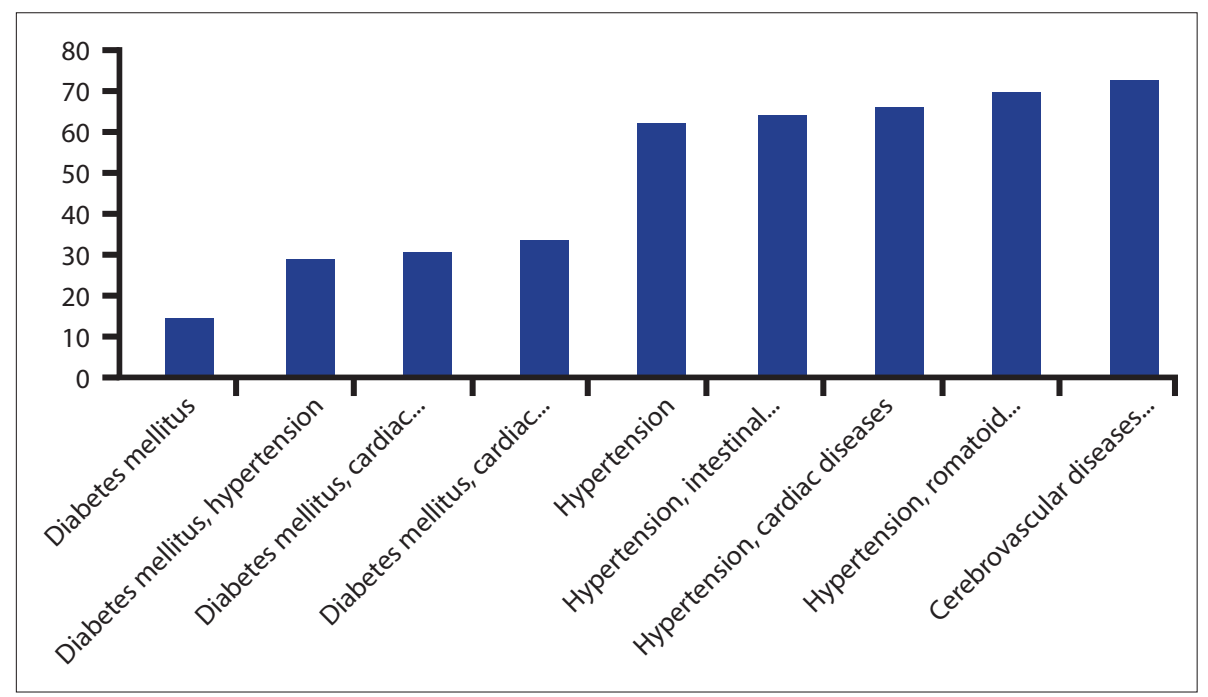

Figure 1. Comorbidities of the patients. 
significant difference between the patients with severe symptoms and the patients with mild to moderate symptoms in terms of clinical and laboratuary parameters $(p>0.05)$. Comorbidities are shown in Figure 1 . There was a negative correlation between IRLSSG score and SF-36 Physical Score, Mental Score and Total Score respectively $(\mathrm{p}=0.018 \mathrm{r}=-0.351, \mathrm{p}=0.01$ $\mathrm{r}=-0.380, \mathrm{p}=0.00 \mathrm{r}=-0.499)$. There was also significant negative correlation between IRLSSG score and SF-36 subscales (Table 3). No significant relation was found between SF-36 subcales and dialysis duration, ferritin and PTH values $(p>0.05)$.

There was no significant correlation between IRLSSG score and age, gender, dialysis duration, blood ferritin and parathyroid hormone and other comorbid diseases.

\section{Discussion}

As a result of this study, $42 \%$ of the patients had restless leg syndrome symptoms and there was a significant relationship between restless leg symptoms and quality of life.

The prevalence of restless leg syndrome among dialysis patients in different study populations is estimated to be between 6.6 and $80 \% .{ }^{[5]}$ This large interval may be explained with the heterogenity of the study populations, like genetic differences and number of patients, and also with the different criteria used to diagnose the syndrome. Using the IRLSSG criteria, the prevelance of RLS in this study was in the range of values, $20-45 \%$, reported by recent studies using the same criteria in Caucasians. ${ }^{[3,5]}$

Many studies have been conducted in dialysis clinics to clarify the risk factors for RLS, but the results have varied widely. We found no significant association between RLS and any of the following factors: age, gender, duration of dialysis and laboratory data including ferritin and parathyroid hormone. There

Table 3. Correlation between SF-36 subscales and IRLLSG, dialysis duration and ferritin and PTH

\begin{tabular}{|c|c|c|c|c|}
\hline & IRLLSG scoring & Dialysis duration & Ferritin & PTH \\
\hline \multicolumn{5}{|l|}{ Physical function } \\
\hline Pearson correlation & $-.311 *$ & $.437^{* *}$ & -.021 & .127 \\
\hline$P$ value & .037 & .003 & .894 & .429 \\
\hline \multicolumn{5}{|l|}{ Role physical } \\
\hline Pearson correlation & -.291 & .060 & .165 & -.106 \\
\hline$P$ value & .052 & .698 & .289 & .509 \\
\hline \multicolumn{5}{|l|}{ General health } \\
\hline Pearson correlation & $-.524^{* *}$ & -.068 & .108 & -.119 \\
\hline$P$ value & .000 & .659 & .491 & .460 \\
\hline \multicolumn{5}{|l|}{ Vitality } \\
\hline Pearson correlation & $-.381^{* *}$ & -.193 & .083 & .024 \\
\hline$P$ value & .010 & .210 & .595 & .884 \\
\hline \multicolumn{5}{|l|}{ Social function } \\
\hline Pearson correlation & $-.463^{* *}$ & .035 & .050 & .010 \\
\hline$P$ value & .001 & .822 & .750 & .949 \\
\hline \multicolumn{5}{|l|}{ Role emotional } \\
\hline Pearson correlation & $-.490^{* *}$ & -.011 & .213 & .244 \\
\hline$P$ value & .001 & .944 & .170 & .124 \\
\hline \multicolumn{5}{|l|}{ Mental health } \\
\hline Pearson correlation & $-.435^{* *}$ & .007 & .218 & -.027 \\
\hline$P$ value & .003 & .964 & .160 & .867 \\
\hline
\end{tabular}

SF: Social Function; IRLSSG: International Restless Legs Syndrome Study Group; PTH: Parathyroid hormone. *Pearson corelation test was used. 
was no association between SF-36 scores and that following factors either.

It is still not well defined what causes RLS in dialysis patients. Common complications of end stage renal disease, anemia, low serum ferritin levels and high serum levels of parathyroid hormone have been linked to RLS. A number of studies suggest that iron deficiency is the major problem since ferrous sulfat therapy, erythropoetin therapy and high-dose iron dextran infusion reduce RLS symptoms. ${ }^{\left[{ }^{9-12]}\right.}$ On the contrary, some recent studies does not support those findings. ${ }^{[13,14]}$ Some researchers suggest that serum ferritin level is not a reliable parameter and according to the findings of low cerebrospinal fluid ferritin and low substansia nigra iron levels, RLS may be due to a problem about brain iron metabolism. ${ }^{[3,15]}$ In this study, RLS was not associated with the presence of iron deficiency, assessed by serum ferritin, either. An association between RLS and parathyroid hormone has been suggested by a few studies in patients undergoing hemodialysis. ${ }^{[14]}$ However, in this study, we determined no relationship between PTH concentrations and RLS as Miranda et al. ${ }^{[12]}$ and Siddiqui et al. ${ }^{[16]}$ There have been studies that measured the relationship between PTH and SF-36 scores in ESRD. Tanaka et al. found a relationship between mental health scores and high PTH levels, whereas Mingardy and Klersy found no association. ${ }^{[17-19]}$

End stage renal disease itself is associated with decreased quality of life. Factors related with the kidney disease, such as medication side effects, psycho-social distress, anxiety, and sleep disorders like RLS have a negative impact on patients' quality of life. Duration of dialysis is estimated to be another reason for decreased life quality. Recent literature indicates the better HRQoL in kidney transplant recipients than patients treated with dialysis. ${ }^{[20]}$ On the other hand, RLS is a chronic condition and people with RLS may have a distinctly impaired quality of life. ${ }^{[15,21]}$

In this study we found a significant correlation between mental, physical and total scores of SF-36 and RLS severity. A cross sectional study conducted on 894 dialysis patients investigated the relation between symptoms of restless legs, quality of life, and survival among incident hemodialysis and peritoneal dialysis patients. Symptoms of restless legs were associated with lower physical and mental component scores of SF-36, vitality, bodily pain, and sleep quality. ${ }^{[13]}$ In another study, the researchers found that RLS was associated with poor sleep, increased rates for insomnia and impaired quality of life in patients on maintenance dialysis. ${ }^{[3]}$ Similar to those findings, Unruh et. al have reported the association between RLS and health related quality of life using SF-36 questionnaire. ${ }^{[13]}$ These results suggest that RLS symptoms have a significant negative effect on already decreased health quality of patients with chronic renal failure.

There are some limitations in this study. First of all is the relatively small sample size. In addition, we did not consider the association between HRQoL and socio-demographic characteristics and comorbidities. Finally, we did not obtain data on electromyographic parameters because most of the patients did not agree to undergo such investigations. On the other hand, we tried to exclude other diseases that could mimic RLS by performing a detailed interview and neurological examination.

\section{Conclusions}

RLS is a common distressing problem in patients with uremic patients and negatively impacts functional health status. The clinicians should be aware of symptoms of RLS to decrease morbidities related with quality of life. More studies with large number of patients are needed.

\section{Conflict-of-interest issues regarding the author- ship or article: None declared.}

\section{Peer-rewiew: Externally peer-reviewed.}

\section{References}

1. Restless legs syndrome: detection and management in primary care. National Heart, Lung, and Blood Institute Working Group on Restless Legs Syndrome. Am Fam Physician 2000;62(1):108-14.

2. Bhatia M, Bhowmik D. Restless legs syndrome in maintenance haemodialysis patients. Nephrol Dial Transplant 2003;18(1):217. CrossRef

3. Sabbatini $M$, Minale $B$, Crispo A. Insomnia in maintenance haemodialysis patients. Nephrol Dial Transplant 2005;20(3):571-7. CrossRef

4. Merlino G, Serafini A, Robiony F, Valente M, Gigli GL. Restless legs syndrome: differential diagnosis and management with rotigotine. Neuropsychiatr Dis Treat 2009;5:67-80. 
5. Al-Jahdali $\mathrm{HH}, \mathrm{Al}-\mathrm{Q} a d h i$ WA, Khogeer HA, Al-Hejaili FF, AlGhamdi SM, Al Sayyari AA. Restless legs syndrome in patients on dialysis. Saudi J Kidney Dis Transpl 2009;20(3):378-85.

6. Chan R, Brooks R, Erlich J, Chow J, Suranyi M. The effects of kidney-disease-related loss on long-term dialysis patients' depression and quality of life: positive affect as a mediator. Clin J Am Soc Nephrol 2009;4(1):160-7. CrossRef

7. Fan SL, Sathick I, McKitty K, Punzalan S. Quality of life of caregivers and patients on peritoneal dialysis. Nephrol Dial Transplant 2008;23(5):1713-9. CrossRef

8. Koçyiğit H, Aydemir Ö, Ozgur B. Kısa Form-36 (KF-36)'nın Türkçe versiyonunun güvenilirliği ve geçerliliği. Ilaç ve Tedavi Dergisi 12(2):102-6

9. O'Keeffe ST, Gavin K, Lavan JN. Iron status and restless legs syndrome in the elderly. Age Ageing 1994;23(3):200-3. CrossRef

10. Harris DC, Chapman JR, Stewart JH, Lawrence S, Roger SD. Low dose erythropoietin in maintenance haemodialysis: improvement in quality of life and reduction in true cost of haemodialysis. Aust N Z J Med 1991;21(5):693-700. CrossRef

11. Sloand JA, Shelly MA, Feigin A, Bernstein P, Monk RD. A double-blind, placebo-controlled trial of intravenous iron dextran therapy in patients with ESRD and restless legs syndrome. Am J Kidney Dis 2004;43(4):663-70. CrossRef

12. Miranda M, Araya F, Castillo JL, Durán C, González F, Arís L. Restless legs syndrome: a clinical study in adult general population and in uremic patients. [Article in Spanish] Rev Med Chil 2001;129(2):179-86. [Abstract]

13. Unruh ML, Levey AS, D'Ambrosio C, Fink NE, Powe NR, Meyer KB. Restless legs symptoms among incident dialysis patients: association with lower quality of life and shorter survival. Am J Kidney Dis 2004;43(5):900-9. CrossRef
14. Collado-Seidel V, Kohnen R, Samtleben W, Hillebrand GF, Oertel WH, Trenkwalder C. Clinical and biochemical findings in uremic patients with and without restless legs syndrome. Am J Kidney Dis 1998;31(2):324-8. CrossRef

15. Earley CJ, Silber MH. Restless legs syndrome: understanding its consequences and the need for better treatment. Sleep Med 2010;11(9):807-15. CrossRef

16. Siddiqui S, Kavanagh D, Traynor J, Mak M, Deighan C, Geddes C. Risk factors for restless legs syndrome in dialysis patients. Nephron Clin Pract 2005;101(3):c155-60. CrossRef

17. Tanaka M, Yamazaki S, Hayashino Y, Fukuhara S, Akiba T, Saito $A$, et al. Hypercalcaemia is associated with poor mental health in haemodialysis patients: results from Japan DOPPS. Nephrol Dial Transplant 2007;22(6):1658-64. CrossRef

18. Mingardi G, Cornalba L, Cortinovis E, Ruggiata R, Mosconi P, Apolone $\mathrm{G}$. Health-related quality of life in dialysis patients. A report from an Italian study using the SF-36 Health Survey. DIA-QOL Group. Nephrol Dial Transplant 1999;14(6):1503-10.

19. Klersy C, Callegari A, Giorgi I, Sepe V, Efficace E, Politi P; Pavia Working Group on QoL in Organ Transplant. Italian translation, cultural adaptation and validation of KDQOL-SF, version 1.3, in patients with severe renal failure. J Nephrol 2007;20(1):43-51.

20. Kovacs AZ, Molnar MZ, Szeifert L, Ambrus C, Molnar-Varga $M$, Szentkiralyi A, et al. Sleep disorders, depressive symptoms and health-related quality of life-a cross-sectional comparison between kidney transplant recipients and waitlisted patients on maintenance dialysis. Nephrol Dial Transplant 2011;26(3):1058-65. CrossRef

21. Salas RE, Gamaldo $C E$, Allen RP. Update in restless legs syndrome. Curr Opin Neurol 2010;23(4):401-6. CrossRef 